\title{
Modular greening technologies for buildings
}

\author{
Elena Korol $^{1}$, Natalia Shushunova ${ }^{1 *}$, Maria Nikitina $^{1}$, Tatiana Shushunova ${ }^{2}$ \\ ${ }^{1}$ Moscow State University of Civil Engineering, Yaroslavskoe shosse, 26, Moscow, 129337, Russia \\ ${ }^{2}$ Mendeleyev University of Chemical Technology of Russia, Miusskaya square, 9, Moscow, 125047, \\ Russia
}

\begin{abstract}
In this research we provide the analysis of the modern green wall technologies. The modular greening technology for the buildings is universal invention with respect to the purpose of the building and it is applicable for greening buildings intended for any spheres of «going into nature» aims. The complexity of installation work of this modular constructive greening system is quite low, which is one of the main advantages of the invention. Due to the fact that the system can be installed both vertically and horizontally, a single coating system of modules is formed. These modules can optimally fill the facades of the building due to the fact that their dimensions can vary. The constructive weight of the system is not large; for this, the technological process is optimized. This system is the most environmentally and technically efficient for the green buildings.
\end{abstract}

\section{Introduction}

Present living in a big city now requires not only well-equipped workplaces but also a healthy atmosphere around. «Clean air and a livable climate are inalienable human rights and solving this crisis is not a question of politics, it is a question of our own survival. This is the most urgent of times, and the most urgent of messages», Leonardo DiCaprio, United Nations Messenger of Peace for Climate, said it on the United Nations Climate Summit in 2014, and this still remains an urgent problem [1].

The arrangement of green systems on rooftops and walls of buildings is a way to improve the quality of our life in the urban space. Z. Azkorra, G. Pérez et al. conducted a study to evaluate the green walls as a passive acoustic insulation system for buildings, they found that green wall have significant potential, and capacity of the green wall to reduce airborne noise, which is expressed by the sound reduction index of $15 \mathrm{~dB}$, was lower than the other constructive and technological solutions [2]. A diverse range of benefits have been associated with greening system, including reduction in $\mathrm{CO} 2$ emissions by $38 \%$, reduction of the airborne noise and energy cost saving of \$1-1,5 Million per year per building and great amount of health benefits [3-5].

Positive results were found by Francesco D'Alessandro et al. in the experimental evaluation and modelling of the sound absorption properties of plants for indoor acoustic applications, they measured the sound absorption of green walls and found the correlation

* Corresponding author: nshushun@gmail.com 
between flow resistivity and leaf area density for the plants like Nephrolepis Exaltata (Boston Fern) [6].

Based on the research of many scientists, it can be concluded that now energy-efficient solutions in housing construction are in great demand [7-9]. E. Palomo developed models for predicting the thermal behavior of buildings roof components designed on the basis of evaporative and radiative cooling principles [10], O. Korol in his research considered the principles of energy efficient construction [11]. The exhaustion of energy resources and heavy environmental impacts were shown in the articles of LuisPérez-Lombard [12] and comfort assessment when designing residential buildings was considerdd by O. Poddaeva, I. Dunichkin and others [13-14]. The use of greening systems leads to an increase in the basic values of the parameters of the laboriousness and duration of work. In order to reduce their growth, a research search is carried out and reserves are formed that take place in the variability of constructive and technological solutions for the walls with greening systems and find the optimal constructive and technological solution of the green wall for the green buildings.

\section{Methodology}

The study applied the methods of comparative analysis of five variants of walls with greening systems, based on the principles of their functionality, labour and time savings of installation process.

At the first, we analyze the devices of the wall covering on the next variants:

$\mathrm{V} 1$ - the variant of walls with greening systems with modular tray;

V2 - the variant of walls with greening systems with ornamental design;

V3 - the variant of walls with greening systems with green wall cladding;

V4 - the variant of walls with greening systems with a growing plants device;

V5 - the variant of walls with greening systems with vertical hydroponics system.

According to the first variant V1, the modular tray is provided for covering a portion of a surface with vegetation in a growth medium. The tray includes a pair of sidewalls, and a lower end wall and an upper end wall extending between and interconnecting the ends of the sidewalls such that the walls define a perimeter of the tray. A bottom wall extends between and interconnects the ends of the sidewalls and the lower end wall and extends in a plane disposed at an angle with the respect to the longitudinal axis of the sidewalls. Each of a plurality of platforms extends between and interconnects the sidewalls and are disposed at an angle with respect to the longitudinal axis of the sidewalls. Each of a plurality of risers extends between the rear edge of a platform to the front edge of an adjacent platform. The tray is water impermeable for accommodating the growth medium and vegetation (figure 1a).

The ornamental design for the green wall system (V2) is shown on the figure $1 \mathrm{~b}$. The green wall cladding system (V3) is provided for the greening walls, including the production of organisms on a green wall cladding system, such as plants and fungi (figure 1c). Modular growing units (V4) are arranged in the frame for the growing units, into which they can be detachably installed with irrigation means (figure 1d). The vertical hydroponics system of walls with greening systems (V5) includes at least one pot coupled to a front surface of the at least one body for supporting one or more plants, and a water source fluidly connected to each body for delivering water uniformly to each pot (figure 1e). 

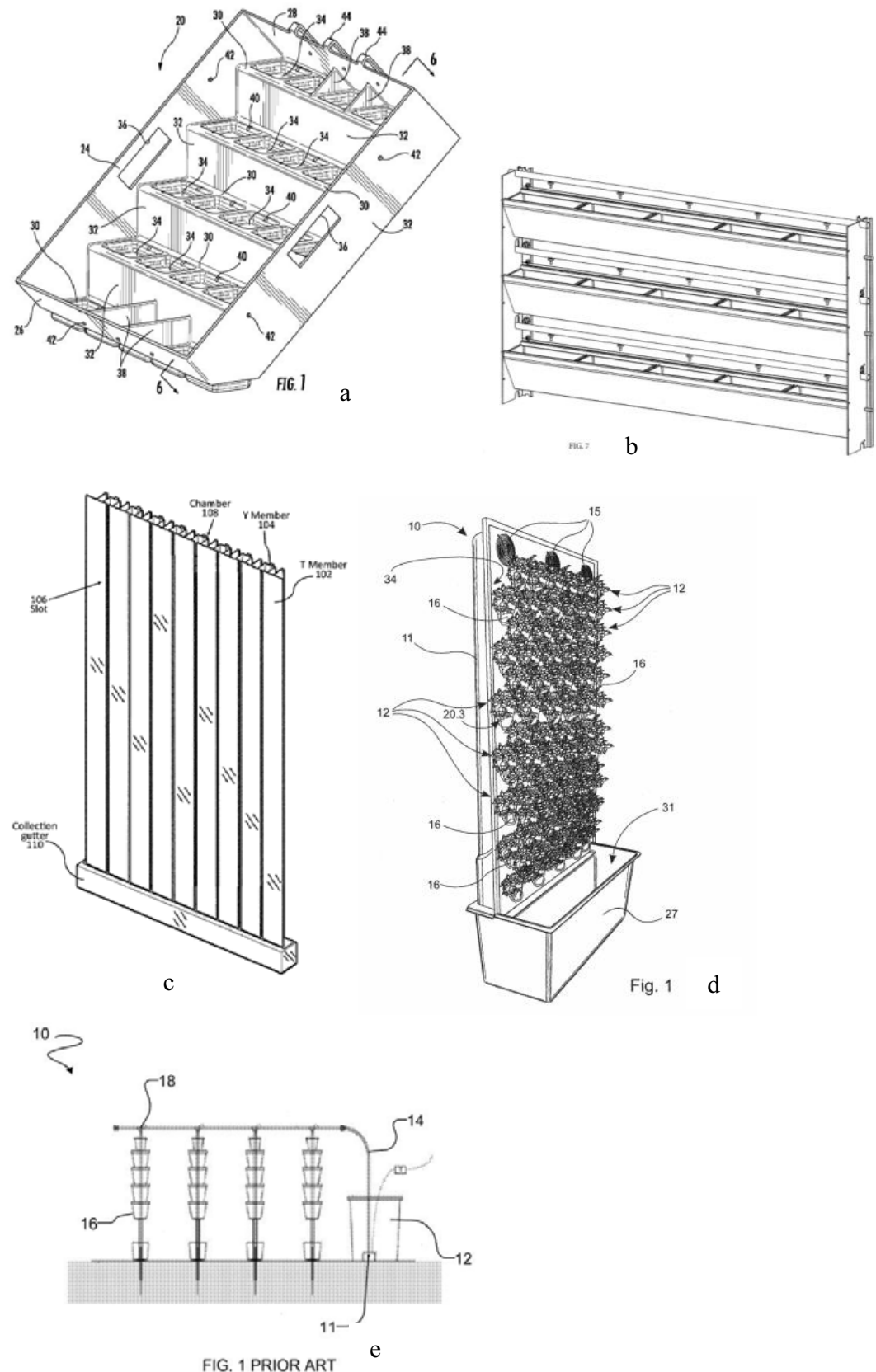

Fig. 1. The variants of walls with greening systems: a - walls with greening systems with modular tray; $\mathrm{b}$ - walls with greening systems with ornamental design; $\mathrm{c}$ - walls with greening systems with green wall cladding; $\mathrm{d}$ - walls with greening systems with a growing plants device; e - walls with greening systems with vertical hydroponics system. 
The comparative analysis of the proposed greening systems for wall covering is presented in the form of table 1 , based on the principles of their functionality, labour and time savings of installation process. The technological indicator of the device of the operated coating with greening systems (It) can be used for a rational choice of the structural and technological solution of the device of the operated coating with greening systems and ranges from 1 (high-ranged) to 5 (low-ranged) the table shows the analysis by an expert assessment method.

Table 1. The comparative analysis of the greening systems for wall covering.

\begin{tabular}{|c|c|c|c|c|}
\hline $\begin{array}{l}\text { Variant } \\
/ \mathbf{I}_{\mathbf{t}}\end{array}$ & $\begin{array}{l}\text { Type of the fastening } \\
\text { system }\end{array}$ & $\begin{array}{l}\text { Type of the } \\
\text { irrigation system }\end{array}$ & $\begin{array}{l}\text { Convenience of } \\
\text { use }\end{array}$ & $\begin{array}{l}\text { Convenience of } \\
\text { installation }\end{array}$ \\
\hline $\begin{array}{l}\text { Variant 1/ } \\
1\end{array}$ & $\begin{array}{l}\text { The system is } \\
\text { quite simple to } \\
\text { operate, adapted to } \\
\text { pitched coatings. } \\
\text { Trays are attached } \\
\text { to each other } \\
\text { tightly, without } \\
\text { gaps, which allows } \\
\text { filling and } \\
\text { maximizing } \\
\text { greening of the } \\
\text { coating }\end{array}$ & $\begin{array}{l}\text { The supply of } \\
\text { nutrients from the } \\
\text { glasses intended } \\
\text { for this design in } \\
\text { which rainwater } \\
\text { for plants } \\
\text { accumulates } \\
\text { occurs through the } \\
\text { holes that are } \\
\text { located on the } \\
\text { sides of the tray } \\
\text { on the sides and } \\
\text { bottom, as well as } \\
\text { on the handles } \\
\text { intended for } \\
\text { mounting the tray }\end{array}$ & $\begin{array}{l}\text { The trays are } \\
\text { made of highly } \\
\text { durable recycled } \\
\text { plastic. The } \\
\text { service life of this } \\
\text { system will be } \\
\text { determined by the } \\
\text { suitability of the } \\
\text { plastic. Plants can } \\
\text { be pre-grown in } \\
\text { modular trays, } \\
\text { thus reducing } \\
\text { installation time }\end{array}$ & $\begin{array}{l}\text { Installed handles } \\
\text { on the sidewalls } \\
\text { are adapted to be } \\
\text { gripped by a } \\
\text { person's hand, } \\
\text { which allows a } \\
\text { person to move } \\
\text { the modular tray } \\
\text { himself }\end{array}$ \\
\hline $\begin{array}{l}\text { Variant } 2 / \\
5\end{array}$ & $\begin{array}{l}\text { The system is } \\
\text { equipped both } \\
\text { with elements of } \\
\text { fasteners to the } \\
\text { wall of the } \\
\text { building, and there } \\
\text { are holes and } \\
\text { fasteners on the } \\
\text { side to connect the } \\
\text { blocks to each } \\
\text { other }\end{array}$ & $\begin{array}{l}\text { The catchment } \\
\text { section can collect } \\
\text { water at any time, } \\
\text { making it easier to } \\
\text { water the plants }\end{array}$ & $\begin{array}{l}\text { The system is } \\
\text { equipped with } \\
\text { multiple seed } \\
\text { drills along the } \\
\text { wall surfaces, } \\
\text { which greatly } \\
\text { simplifies the } \\
\text { system in terms } \\
\text { of operation }\end{array}$ & $\begin{array}{l}\text { Installation takes } \\
\text { place in several } \\
\text { stages, which } \\
\text { allows you to } \\
\text { accurately install } \\
\text { the system, but } \\
\text { installation time } \\
\text { is more longer }\end{array}$ \\
\hline $\begin{array}{l}\text { Variant } 3 \text { / } \\
2\end{array}$ & $\begin{array}{l}\text { Various fastening } \\
\text { methods can be } \\
\text { used depending on } \\
\text { the norms applied } \\
\text { to the building } \\
\text { structure and the } \\
\text { principles of using } \\
\text { this system }\end{array}$ & $\begin{array}{l}\text { The pumping } \\
\text { system moves } \\
\text { water to the top of } \\
\text { the system from } \\
\text { the rooftop } \\
\text { wastewater } \\
\text { storage tank, thus } \\
\text { reducing the load } \\
\text { on the storm drain }\end{array}$ & $\begin{array}{l}\text { High humidity is } \\
\text { maintained in the } \\
\text { plant growing } \\
\text { chamber due to } \\
\text { the constant } \\
\text { movement of } \\
\text { water through the } \\
\text { system pipeline }\end{array}$ & $\begin{array}{l}\text { The system uses } \\
\text { a lightweight } \\
\text { water retention } \\
\text { system, which } \\
\text { allows for ease of } \\
\text { installation }\end{array}$ \\
\hline $\begin{array}{l}\text { Variant } 4 \text { / } \\
4\end{array}$ & $\begin{array}{l}\text { Constructive } \\
\text { solutions of this } \\
\text { design have a wide } \\
\text { range, which } \\
\text { allows technician } \\
\text { to attach the }\end{array}$ & $\begin{array}{l}\text { The cylindrical } \\
\text { irrigation system } \\
\text { allows irrigation of } \\
\text { the substrate } \\
\text { by automatic } \\
\text { gravity without }\end{array}$ & $\begin{array}{l}\text { Simplicity of } \\
\text { design and easy } \\
\text { change of plants, } \\
\text { for which the } \\
\text { trays are located } \\
\text { independently of } \\
\text { the irrigation } \\
\text { system, allow for }\end{array}$ & $\begin{array}{l}\text { This system can } \\
\text { be designed in } \\
\text { different sizes }\end{array}$ \\
\hline
\end{tabular}




\begin{tabular}{|c|c|c|c|c|}
\hline & $\begin{array}{l}\text { system to various } \\
\text { types of structures }\end{array}$ & $\begin{array}{l}\text { unnecessary } \\
\text { structures. This } \\
\text { type of irrigation } \\
\text { is practically not } \\
\text { maintained during } \\
\text { operation }\end{array}$ & $\begin{array}{l}\text { efficient } \\
\text { operation }\end{array}$ & \\
\hline $\begin{array}{l}\text { Variant } 5 \text { / } \\
3\end{array}$ & $\begin{array}{l}\text { The irrigation } \\
\text { source is smoothly } \\
\text { connected to each } \\
\text { body, so the water } \\
\text { supply is } \\
\text { distributed evenly } \\
\text { to the plants }\end{array}$ & $\begin{array}{l}\text { The irrigation } \\
\text { source is smoothly } \\
\text { connected to each } \\
\text { body, so the water } \\
\text { supply is } \\
\text { distributed evenly } \\
\text { to the plants }\end{array}$ & $\begin{array}{l}\text { The drip } \\
\text { irrigation system } \\
\text { allows the } \\
\text { structure to be } \\
\text { regularly serviced } \\
\text { during operation } \\
\text { by replacing the } \\
\text { aqueous solution }\end{array}$ & $\begin{array}{l}\text { The structure is } \\
\text { suspended on the } \\
\text { wall surface, } \\
\text { occupying a } \\
\text { small area, and } \\
\text { can also be } \\
\text { installed on a } \\
\text { special stand }\end{array}$ \\
\hline
\end{tabular}

\section{Results}

The system with special handles on the sidewalls (variant 1) is more adapted to be installed by a person's hand and has high technological indicator of the device of the operated covering with greening systems, It $1=1$, as opposed to the less technological variant 2 , where installation process takes place in several stages, It $2=5$. At the same time, the device of the modular greening system is more rational both in terms of labour costs and the duration of the work, in comparison with other variants.

The green wall modules, designed by authors (Fig. 2a, 2b, 2c) were composed of a rectangular plastic module $(1000 \mathrm{~mm} \times 1000 \mathrm{~mm} \times 191 \mathrm{~mm})$ with the permeable bags containing a plant-growing medium composed of coarse $(25 \mathrm{~mm}$ particle size) coconut husks and the fiber. The front part of each module panel has 4 (or 5) openings for the plants, which protrude out from the bag inside, plant roots are imbedded within the medium.

The considered variants for the design of wall covering with greening systems are determined by various values of the laboriousness of technological processes and operations (figure 2). 


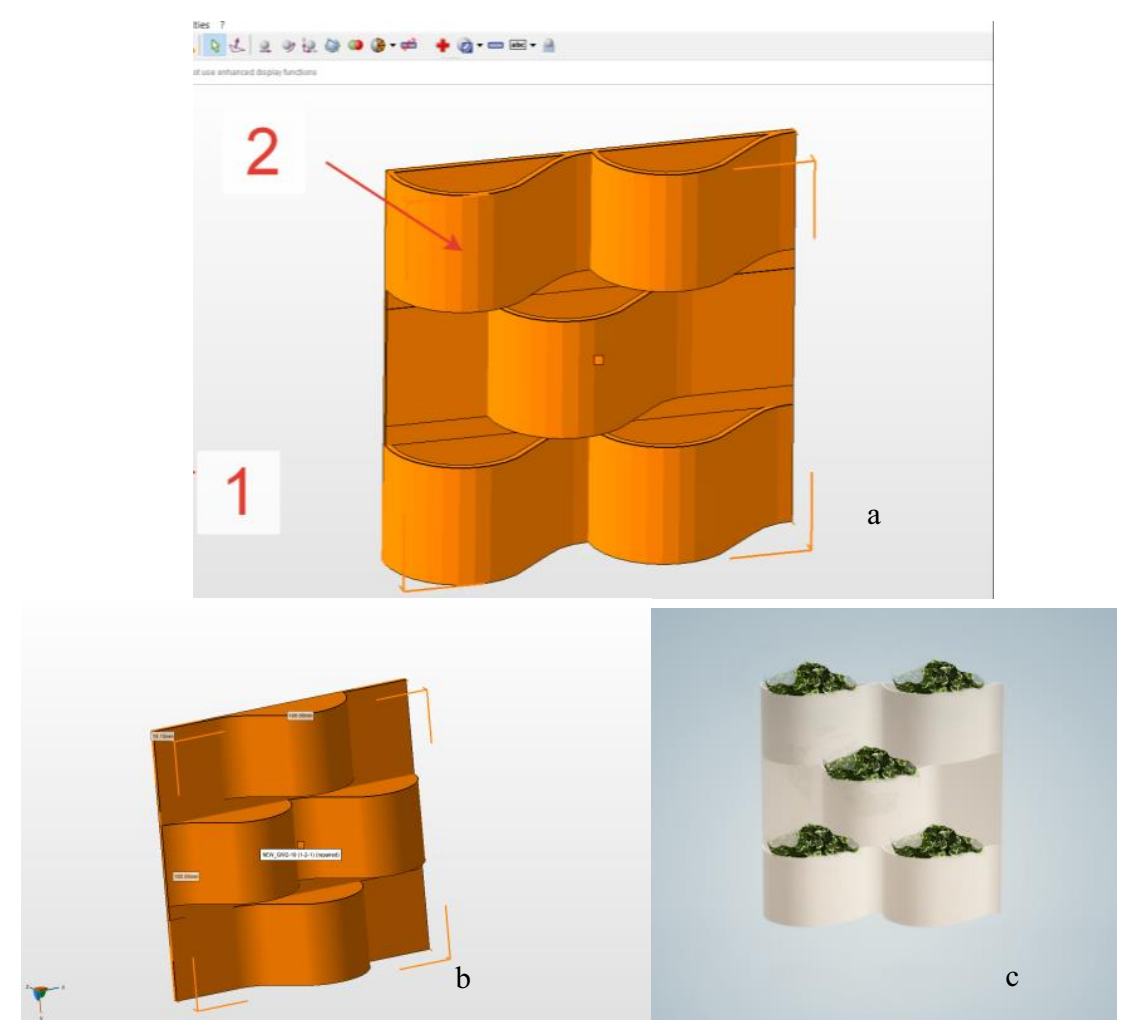

Fig. 2. The modular green wall system, designed by authors: 1 - software interface; 2 - unit for plant; $\mathrm{a}$ - first modification of green wall module; $\mathrm{b}$ - second modification of green wall module; $\mathrm{c}$ - green wall module with vegetation.

The main advantages of the green wall system, of developed and patented by the authors, are the following: unique wavy-continued design, pre-vegetated green wall modules, which may be transported to a second location, such as a dwelling or business center, where modules may be arranged in a grid-like fashion to cover one or more walls of the home or business as described above. In this manner, the pre-vegetated green wall may be installed in a relatively short period of time. Green wall modules, designed by authors, have unique characteristics: very lightweight structures, easy to install, unique irrigation system and modules may be installed on the side of structures, such as internal and external walls of the buildings. The principles and methods of energy optimization for maximizing solar systems output were carried out in the articles of foreign scientists $[15,16]$. P. Bevilacqua in his research studies energy efficiency, renewable sources and passive systems for the buildings [17-20].

These studies determined the 5 different greening systems for wall covering and found their similarities, differences, significant advantages and disadvantages of some systems. The trays of the greening systems of variant 1 are attached to each other tightly, without gaps, which allows filling and maximizing greening of the coating and trays are adapted to be gripped by a person's hand, which allows a person to move the modular tray himself, which is good option for installation process. The variability of fastening systems and easy irrigation system with water-catchment section are features of green wall systems and (variant 2 and variant 3). Green wall systems (variant 4, 5) are discerned the convenient 
watering system and modular pot designs. These studies were carried out taking into account the assessment of the experimental extensive green roof data [21].

\section{Conclusions}

This study employs a system modelling approach to analyse the alternative green wall systems, as well as the potential of societal, economic, and developmental investments in different alternative green wall systems to address these issues. The developed structural and technological solution of walls with modular greening systems provides for the reduction of labour-intensive processes when analyzed at the building level. Making more explicit the multiple benefits of sustainable buildings with greening systems needs further consideration in this regard. We would like to take key actions to accelerate the number of green initiatives for the buildings and offer the more improved solutions. The authors proposed new constructive and technological solutions for wall covering - green wall modules of two types, designed by authors, may be installed on the side of different building structures, such as internal and external walls. Lightweight constructive, simplicity of installation and ease of maintenance as well as a unique staggered design are the absolute advantages of this system.

\section{References}

1. Available online: https://www.leonardodicaprio.org/leonardo-delivers-landmarkspeech-at-the-united-nations-climate-summit/

2. Azkorra Z., Pérez G., Coma J., et al. Evaluation of green walls as a passive acoustic insulation system for buildings, Appl. Acoust., 89 (2015) https://doi.org/10.1016/j.apacoust.2014.09.010.

3. Pérez-Urrestarazu L, Fernández-Cañero R, Franco A, Egea G, Ecol. Eng. 90 (2016) https://doi.org/10.1016/j.ecoleng.2016.01.050.

4. Abdo P, Phuoc H, Irga P, Torpy F, Urban Forestry \& Urban Greening, 41 (2019) https://doi.org/10.1016/j.ufug.2019.03.013.

5. Balaban O., Puppim de Oliveira J. Sustainable buildings for healthier cities: assessing the co-benefits of green buildings in Japan, Journal of Cleaner Production, 163, (2017) https://doi.org/10.1016/j.jclepro.2016.01.086.

6. D'Alessandro F., Asdrubali F., Mencarelli N., Experimental evaluation and modelling of the sound absorption properties of plants for indoor acoustic applications, Build. and Env., 94 (2015) https://doi.org/10.1016/j.buildenv.2015.06.004.

7. Li M, Yang J, Resour. Conserv. Rec. 93 (2014)

8. Beazley S., Heffernan E., McCarthy T., Energ. Procedia, 121, (2017)

9. Bruno R. and Arcuri N. et al. The Passive House in Mediterranean Area: Parametric Analysis and Dynamic Simulation of the Thermal Behaviour of an Innovative Prototype, Energy Procedia, 82, (2015) DOI: 10.1016/j.egypro.2015.11.866

10. Palomo E. Energ. Buildings, 29 259-81 (1999) DOI: 10.1016/S0378-7788(98)00061-9

11. Korol O. Constr. Mater. 6 pp 3-15 (2015)

12. Pérez-lombard L., Ortiz J. and Pout C. Energ. Buildings 40 (2007) DOI: 10.1016/j.enbuild.2007.03.007

13. Poddaeva O., Dunichkin I., Gribach J. Web of Conferences 6403013 (2018) https://doi.org/10.1051/shsconf/20196403013 
14. Santos R., Costa A., Silvestre J., Pyl L. Aut. in Const. 103, (2019)

15. Soust-Verdaguer B., Llatas C., García-Martínez A. Energ. Buildings, 136, (2017)

16. Mousazadeh H., Keyhani A., Javadi A., Mobli H., Abrinia K., Sharifi A., A review of principle and sun-tracking methods for maximizing solar systems output. Ren. and Sust. Energ. Reviews, 13, (2009)

17. Bruno R., Bevilacqua P., Longo L., Arcuri N. Small Size Single-axis PV Trackers: Control Strategies and System Layout for Energy Optimization, Energ. Procedia, 82, (2015)

18. Bevilacqua P., Mazzeo D., Bruno R. and Arcuri N. Energy and Buildings, 122, (2016) DOI: $10.1016 /$ j.enbuild.2016.03.062

19. Bevilacqua P., Mazzeo D., and Arcuri N. Thermal inertia assessment of an experimental extensive green roof in summer conditions, Building and Environment, 131 (2017) DOI: 10.1016/j.buildenv.2017.11.033

20. Bevilacqua P., Mazzeo D., Bruno R. and Arcuri N. Surface temperature analysis of an extensive green roof for the mitigation of urban heat island in southern mediterranean $\begin{array}{llll}\text { climate, Energy and } & \mathbf{1 5 0} \text { (2017) }\end{array}$ https://doi.org/10.1016/j.enbuild.2017.05.081

21. Carbone M., Garofalo G., Nigro G. et al. Green Roofs in the Mediterranean Area: Interaction between Native Plant Species and Sub-Surface Runoff, Appl. Mech. and Mat., 737, (2015) DOI: 10.4028/www.scientific.net/AMM.737.749 